\title{
Effect of lactation stage and energy status on milk fat composition of Holstein-Friesian cows
}

\author{
W. M. Stoop, ${ }^{* 1}$ H. Bovenhuis, ${ }^{*}$ J. M. L. Heck, $†$ and J. A. M. van Arendonk* \\ ${ }^{*}$ Animal Breeding and Genomics Centre, Wageningen University, PO Box 338, $6700 \mathrm{AH}$ Wageningen, the Netherlands \\ †Dairy Science and Technology, Wageningen University, PO Box 8129, 6700 EV Wageningen, the Netherlands
}

\begin{abstract}
The effects of lactation stage, negative energy balance (NEB), and milk fat depression (MFD) were estimated on detailed milk fat composition in primiparous Holstein-Friesian cows. One morning milk sample was collected from each of 1,933 cows from 398 commercial Dutch herds in winter 2005. Milk fat composition was measured using gas chromatography, and fat and protein percentage were measured using infrared spectrometry. Each fatty acid changed 0.5 to 1 phenotypic standard deviation over lactation, except odd-chain C5:0 to C15:0, branched-chain fatty acids, and trans-10, cis-12 conjugated linoleic acid (CLA). The greatest change was an increase from 31.2 to $33.3 \%$ (wt/wt) for C16:0 from d 80 to 150 of lactation. Energy status was estimated for each cow as the deviation from each average lactation fat-to-protein ratio (FPdev). A high FPdev $(>0.12)$ indicated NEB. Negative energy balance was associated with an increase in C16:0 (0.696 \pm 0.178) and C18:0 $(0.467 \pm 0.093)$, which suggested mobilization of body fat reserves. Furthermore, NEB was associated with a decrease in odd-chain C5:0 to C15:0 ( $-0.084 \pm 0.020)$, which might reflect a reduced allocation of $\mathrm{C} 3 \mathrm{com}-$ ponents to milk fat synthesis. A low FPdev indicated MFD $(<-0.12)$ and was associated with a decrease in C16:0 $(-0.681 \pm 0.255)$ and C18:0 $(-0.128 \pm 0.135)$ and an increase in total unsaturated fatty acids $(0.523$ $\pm 0.227)$. The study showed that both lactation stage and energy balance significantly contribute to variation in milk fat composition and alter the activity of different fatty acid pathways.
\end{abstract}

Key words: fatty acid, milk composition, lactation stage, dairy cattle

\section{INTRODUCTION}

The dairy industry has focused on improving specific health aspects of dairy products, and recent studies on

Received June 20, 2008.

Accepted November 10, 2008

${ }^{1}$ Corresponding author: Marianne.Stoop@wur.nl milk fat have sought to identify factors affecting milk fat composition (German and Dillard, 2006). Milk fat composition changes with lactation stage. Karijord et al. (1982) found, in a limited number of fatty acids (FA) in 3,000 Norwegian cows, that proportions of C6:0 to C14:0 FA peaked around the third month of lactation. Proportions of $\mathrm{C} 18 \mathrm{FA}$, on the other hand, reached a minimum around the third month (Karijord et al., 1982; Syrstad et al., 1982; Palmquist and Beaulieu, 1993). More recent studies on approximately 20 cows showed similar trends for Holstein cows (Kay et al., 2005; Garnsworthy et al., 2006).

Milk FA originate from 4 major pathways: directly from the diet, de novo synthesis in the mammary gland, formation in the rumen by biohydrogenation or bacterial degradation, and release from body fat stores (Chilliard et al., 2000; MacGibbon and Taylor, 2006). Changes in milk fat composition over lactation imply shifts in the activity of these pathways and were related to changes in energy status of the cow (Van Knegsel et al., 2005). The fat-to-protein ratio (FPratio) was proposed as an indicator of energy status (Grieve et al., 1986; Friggens et al., 2007a). A high FPratio indicates low or negative energy balance (NEB), the combined result of elevated fat percentage and decreased milk and protein yield. Van Knegsel et al. (2005) suggested that during NEB, de novo synthesis of FA (C6:0 to C14:0) was reduced and body fat reserves addressed. A low FPratio, on the other hand, reflects milk fat depression (MFD), a dietary problem causing an energy imbalance and possibly acidosis in the rumen (Bauman and Griinari, 2003; Bauman et al., 2008; Plaizier et al., 2008), the result of decreased milk fat percentage with no effect on milk or protein yield. Bauman et al. (2008) suggested that during diet-induced MFD, levels of conjugated linoleic acid (CLA) were increased, which inhibited de novo synthesis resulting in decreased levels of saturated FA.

Studies on NEB and MFD have traditionally been limited to small nutrition studies that focus mainly on the first weeks after calving. Data on the effect of energy balance on milk fat composition are scarce. The aim was to estimate the effect of lactation stage and energy status throughout lactation on detailed milk 
Table 1. Overview of studied fatty acids and fatty acid groups

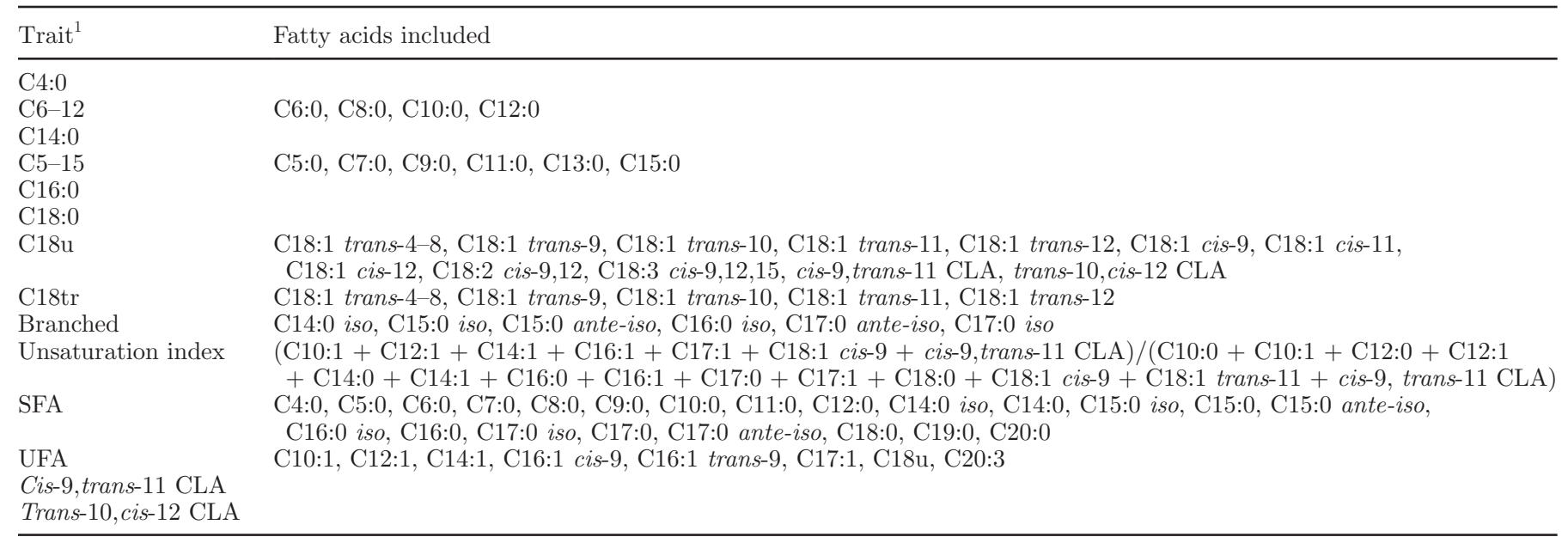

${ }^{1} \mathrm{C} 18 \mathrm{u}=$ unsaturated $\mathrm{C} 18$ fatty acids; C18tr = trans $\mathrm{C} 18$ fatty acids; SFA = saturated fatty acid; UFA = unsaturated fatty acid; CLA = conjugated linoleic acid.

fat composition in a large population of first-lactation Holstein-Friesian cows kept on commercial farms across feeding regimens.

\section{MATERIALS AND METHODS}

\section{Cows}

This study was part of the Dutch Milk Genomics Initiative, which was designed to have approximately 2,000 cows descending from several selected bulls; the aim was to have 50 young bulls each with 20 daughters and 5 proven bulls each with 200 daughters. The pedigree was the main reason for the choice of cows and farms, but at least 3 cows per farm were selected. Selected farms reflected housing and feeding regimens across the Netherlands.

Data were available for 1,933 cows from 398 commercial herds in the Netherlands to study milk fat composition. Each cow was between d 63 and 282 of first lactation and was $>87.5 \%$ Holstein-Friesian. The pedigree of each cow was available from the Dutch herd book (NRS, Arnhem, the Netherlands). All cows were housed indoors during the winter period when the milk samples were collected. Cows were milked twice daily, but 1 composite morning milk sample of $500 \mathrm{~mL}$ per cow was collected in February or March 2005. Sample bottles contained sodium-azide $(0.03 \% \mathrm{wt} / \mathrm{wt})$ for preservation of milk samples.

\section{Sample Analysis}

Milk fat (butter) was extracted from about $400 \mathrm{~mL}$ of milk, with the remaining $100 \mathrm{~mL}$ of milk kept at $-40^{\circ} \mathrm{C}$ for other analyses. Fatty acid methyl esters were prepared from milk fat as described in ISO Standard 15884 (IDF, 2002a). The FA methyl esters were analyzed using GC according to the 100\% FAME method (IDF, 2002b) with a 100-m polar column (Varian Fame Select CP 7420, Varian Inc., Palo Alto, CA) at the laboratory of the Netherlands Controlling Authority For Milk and Milk Products (Leusden, the Netherlands). The FA methyl ester chromatograms of the milk fat samples were compared with chromatograms of pure FA methyl ester standards to identify and quantify the FA. The FA were measured as weight-proportion of total fat weight.

The following FA and groups of FA were studied (Table 1): C4:0; even-chain C6:0 to 12:0 (C6-12); oddchain C5:0 to C15:0 (C5-15); C14:0; C16:0; C18:0; unsaturated $\mathrm{C} 18$ (C18u); trans $\mathrm{C} 18$ (C18tr); saturated fatty acids (SFA); unsaturated fatty acids (UFA); branched FA; cis-9,trans-11 CLA and trans-10,cis-12 CLA; and the unsaturation index. The unsaturation index was calculated as (cis-9 FA)/(cis-9 FA + substrate). Percentages of fat and protein were determined from a 10-mL milk subsample by infrared spectroscopy using a Fourier transformed interferogram (MilkoScan FT 6000, Foss Electric, Hillerød, Denmark) at the certified laboratory of the Milk Control Station (Zutphen, the Netherlands).

\section{Statistical Analyses}

Data analysis was performed using an animal model in AS-Reml (Gilmour et al., 2002). This analysis enabled a simultaneous estimation of the effect of lactation stage while correcting for several other environmental and genetic factors. The base model was 


$$
\begin{aligned}
\mathrm{y}_{\mathrm{ijklmn}}=\mu & + \text { lactation stage }_{\mathrm{i}}+\text { scode }_{\mathrm{j}}+\operatorname{afc}_{\mathrm{k}} \\
& +\operatorname{herd}_{1}+\mathrm{A}_{\mathrm{m}}+\mathrm{e}_{\mathrm{ijklm}},
\end{aligned}
$$

where $\mathrm{y}_{\mathrm{ijklmn}}=$ dependent variable corresponding to the observation of animal $m$ in herd $l$, with scode $j$, age at first calving $k$, and lactation stage $i ; \mu=$ general mean; lactation stage $_{i}=$ fixed effect for 10 classes of lactation stage; scode $_{j}=$ fixed effect accounting for a different genetic level between the groups of proven bull daughters and young bull daughters; afc $_{\mathrm{k}}=$ fixed effect for 9 classes of age at first calving; herd $_{1}=$ random effect defining groups of animals sampled in the same herd; $\mathrm{A}_{\mathrm{m}}=$ random additive genetic effect of animal $m$; and $\mathrm{e}_{\mathrm{ijklm}}=$ random residual effect.

To study the effect of lactation stage on milk fat composition, 10 classes of lactation stage were modeled: $<85$ DIM (n= 40); 85 to $104(\mathrm{n}=83) ; 105$ to $124(\mathrm{n}=$ $175) ; 125$ to $144(\mathrm{n}=280) ; 145$ to $164(\mathrm{n}=325) ; 165$ to $184(\mathrm{n}=337) ; 185$ to $204(\mathrm{n}=307) ; 205$ to $224(\mathrm{n}=$ $247) ; 225$ to $244(\mathrm{n}=102)$; and $>244$ DIM $(\mathrm{n}=37)$.

De Vries and Veerkamp (2000) proposed that a deviation from average FPratio might be a better variable for energy balance than simple FPratio, as it avoids that cows with high genetic merit for fat are always defined as having a high FPratio, and consequently NEB. Energy balance for each cow was estimated by the deviation of the FPratio (FPdev) in the milk sample from the average FPratio over first lactation for each cow based on approximately 7 test days; for each

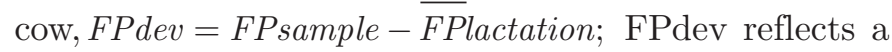
deviation from an individual lactation average and can be seen as an indicator for temporary physiological changes specific to that cow. Three classes of FPdev were defined: $<-0.12(\mathrm{MFD}, \mathrm{n}=174)$; between 0.12 and -0.12 (normal, $\mathrm{n}=1,511)$; and $>0.12(\mathrm{NEB}, \mathrm{n}=$ 247). For 1 animal, data for FPdev were missing because fat and protein percentage data were not available. An FPdev of -0.12 corresponded to an average decrease in fat percentage of approximately $0.4 \%$, which was described as threshold for MFD (Calus et al., 2005). An FPdev of 0.12 corresponded to an average FPratio of 1.35, which approximated values for NEB reported in literature (Grieve et al., 1986; Heuer et al., 1999). To calculate the effect of FPdev on milk fat composition, model [2] was used:

$$
\begin{gathered}
\mathrm{y}_{\mathrm{ijklmn}=\mu+} \operatorname{FPdev}_{\mathrm{i}}+\operatorname{scode}_{\mathrm{j}}+\operatorname{afc}_{\mathrm{k}}+\operatorname{herd}_{1} \\
+\mathrm{A}_{\mathrm{m}}+\mathrm{e}_{\mathrm{ijklm}},
\end{gathered}
$$

where $\mathrm{FPdev}_{\mathrm{i}}=$ fixed effect for 3 classes of FPdev: MFD, normal, and NEB.
To study whether FPdev could explain the effects of lactation stage, 3 models were compared: the base model [1] with lactation stage as fixed effect; the FPdev model [2] without lactation stage but with FPdev as fixed effect; and finally the full model [3], with both lactation stage and FPdev as fixed effects. First, Fvalues for lactation stage (models [1] and [3]) or FPdev (models [2] and [3]) were compared to assess changes in significance of lactation stage or FPdev. Second, the sizes of the estimated effects for lactation stage or FPdev were compared.

\section{RESULTS}

\section{Average Milk Fat Composition}

The mean composition of milk fat of the 1,933 cows is given in Table 2. Short-chain FA (C4 and C6-12) averaged about $14 \%$ (wt/wt) of fat; medium-chain FA (C14:0 and C16:0) were $>44 \%$, making them the largest contributor; and long-chain FA (C18:0 and C18u) were about $30 \%$. Approximately $71 \%$ (wt/wt) of the fat was analyzed as SFA, $26 \%$ as UFA, and $3 \%$ of the fat was unidentified, but was likely unsaturated. Trans10,cis-12 CLA occurred only in trace amounts and was below the detection limit in 1,784 of 1,933 samples.

\section{Changes in Milk Fat Composition with Lactation Stage}

The changes in FA proportions during lactation are shown in Figure 1, panels A to N. The first yaxis shows the amount (\% wt/wt) for that FA. The second $\mathrm{y}$-axis ranges from -1 to +1 phenotypic SD, which facilitates comparison across FA. For most FA, cows in the last stage of lactation stage (>244 DIM) had slightly deviating means and greater standard errors, which is likely due to the relatively low number of 37 cows in this class. Lactation stage significantly affected all FA except for C5-15, branched, and trans10,cis-12 CLA. The amount of C16:0 increased from d 80 to 150 of lactation, from 31.2 to $33.3 \%$ (wt/wt), and remained relatively stable thereafter. The amount of C18:0 decreased from d 80 to 150 of lactation, from 9.8 to $8.4 \%$ (wt/wt). Saturated FA showed a large change over lactation, increasing during the first half of lactation and then decreasing from 71.5 to $69.7 \%$ (wt/ wt). The patterns for C18u, UFA, and the unsaturation index were similar to one another and showed a minimum at mid-lactation, with UFA being $1.5 \%$ (wt/wt) lower in mid-lactation than in early and late lactation. The trans FA (C18:1 trans-4-8, C18:1 trans-9, C18:1 trans-10, C18:1 trans-11, and C18:1 trans-12) decreased 
Table 2. Mean \pm SD, coefficient of variation (CV), and 5 and $95 \%$ quantiles for fatty acids (FA) measured in a test-day morning milk sample from 1,933 cows in first lactation ${ }^{1}$

\begin{tabular}{lrrrrr}
\hline Trait & Mean $^{2}$ & SD & CV $(\%)$ & $5 \%$ quantile & $95 \%$ quantile \\
\hline C4:0 & 3.50 & 0.27 & 8 & 3.05 & 3.96 \\
C6-12 & 10.74 & 1.23 & 11 & 8.70 & 12.72 \\
C14:0 0 & 11.62 & 0.91 & 8 & 10.03 & 13.01 \\
C5-15 & 1.47 & 0.32 & 22 & 1.09 & 2.02 \\
C16:0 & 32.61 & 2.81 & 9 & 28.07 & 37.11 \\
C18:0 & 8.73 & 1.42 & 16 & 6.55 & 11.07 \\
C18tr & 1.50 & 0.43 & 29 & 1.00 & 2.14 \\
C18u & 21.58 & 2.43 & 11 & 18.19 & 26.16 \\
Branched & 0.61 & 0.10 & 16 & 0.48 & 0.80 \\
Unsaturation index & 0.26 & 0.03 & 12 & 0.22 & 0.31 \\
Unsaturated FA & 25.74 & 2.51 & 10 & 22.24 & 30.39 \\
Saturated FA & 70.84 & 2.74 & 4 & 65.99 & 74.75 \\
Cis-9,trans-11 CLA & 0.39 & 0.11 & 28 & 0.25 & 0.59 \\
Trans-10, cis-12 CLA & 0.00 & 0.01 & $\mathrm{NA}^{3}$ & 0.00 & 0.02
\end{tabular}

${ }^{1}$ Groups are defined in Table 1.

${ }^{2}$ For each FA, mean = mean FA as wt/wt proportion of the total fat fraction of $100 \%$.

${ }^{3}$ Trans-10,cis-12 conjugated linoleic acid (CLA) is 0.00 in 1,784 out of 1,933 samples, so CV is not available.

slightly with lactation stage, except for C18:1 trans-11, which increased in the second half of lactation (d 150 to 300$)$.

\section{Changes in Milk Fat Composition with Energy Status}

Composition of milk production traits for each FPdev class is given in Table 3. Compared with cows in the normal group, cows with MFD (FPdev $<-0.12$ ) had a decrease in fat percentage of $0.6 \%$ without changes in protein or milk yield. Cows with NEB had an increase of $0.6 \%$ in fat percentage, no change in fat yield, and decreased protein $(0.06 \mathrm{~kg})$ and milk yield $(1.2 \mathrm{~kg})$ compared with normal cows.

The milk fat composition for each FPdev class is given in Table 4. Results for MFD (FPdev <-0.12) and NEB (FPdev $>0.12$ ) are shown as deviation from normal $(<-0.12$ FPdev $>0.12)$. Animals with MFD had $0.52 \%$ (wt/wt) more UFA compared with normal cows, mainly because of an increase of $0.44 \%$ (wt/ wt) in $\mathrm{C} 18 \mathrm{u}$. In addition, the unsaturation index was slightly increased, which might reflect increased desaturase activity. Animals with MFD had $0.62 \%$ (wt/wt) less SFA, mainly because of a decrease of $0.68 \%$ (wt/ wt) in C16:0 and a decrease of $0.13 \%$ (wt/wt) in C18:0, whereas the amount of $\mathrm{C} 6-12$ was slightly increased (0.14\% wt/wt).

Animals with NEB had less C6-12, C5-15, and C14:0 than normal cows, whereas their levels of C16:0 increased $0.70 \%$ (wt/wt) compared with normal cows. This resulted in an overall increase in SFA of $0.45 \%$ (wt/wt), whereas UFA decreased by $0.37 \%$ (wt/wt). Cows with MFD had greater levels of C18tr compared with normal cows. Cows in NEB had $1.38 \%$ (wt/wt) more C16:0 than MFD cows and 1.07\% (wt/wt) more
SFA. Compared with MFD animals, NEB animals had $0.60 \%$ (wt/wt) more $\mathrm{C} 18: 0$ and $0.12 \%$ (wt/wt) less C5-15.

\section{Effects of Lactation Stage and FPdev}

The $F$-values for lactation stage and FPdev from the 3 different statistical models are given in Table 5. In general, $F$-values for lactation stage were slightly decreased (0.04 to 0.27 lower) in model [3] compared with model [1], but the significance and size of the estimates were not affected (Table 5). This suggests that FPdev as energy indicator explained only a minor part of the lactation stage effect.

\section{DISCUSSION}

Milk fat composition significantly changed with lactation stage. The size of the effect was typically 0.5 to 1 phenotypic SD. Energy status, as reflected by FPdev, significantly affected milk fat composition. Changes in milk fat composition due to lactation stage cannot be explained by energy status.

In the current study, C16:0 changed a maximum of $2.1 \%$ (wt/wt) with lactation stage. This change was small compared with differences between herds or sires (Stoop et al., 2008). For C16:0, the difference in estimated herd effect was $8.4 \%$ (wt/wt) between the lowest and the highest herd, implying a large effect of feeding differences on C16:0. Likewise, there was a difference in genetic merit for $\mathrm{C} 16: 0$ between animals of $6.18 \%$ (wt/ wt) implying that genetic selection on C16:0 could lead to large changes in $\mathrm{C} 16: 0$ proportion in milk. The same magnitude of difference was found for other FA, where 

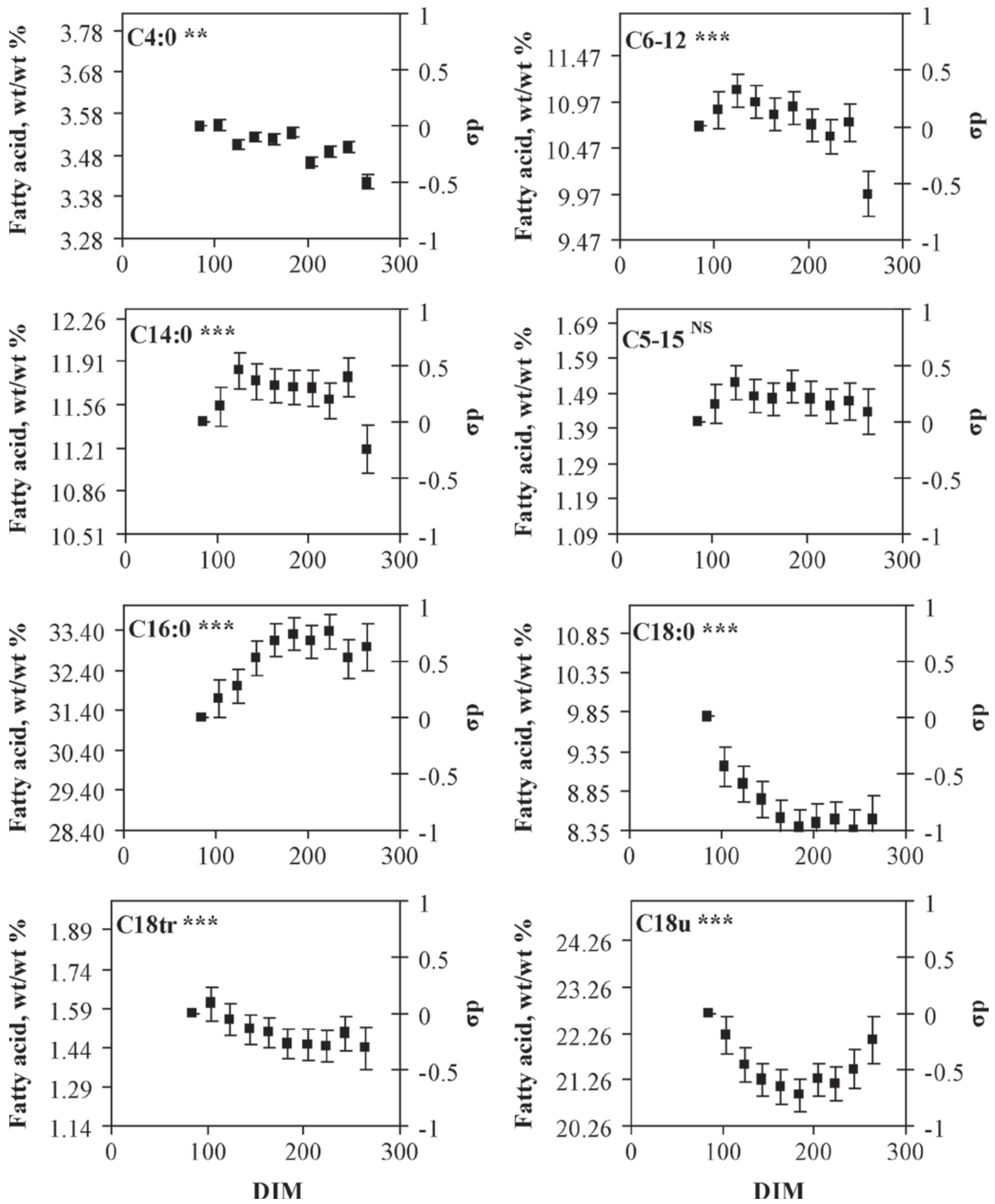

Figure 1. Changes in fatty acid proportions during lactation; x-axis shows days in lactation (DIM); left y-axis shows changes in fatty acid (\% wt/wt); and right y-axis shows relative change in phenotypic standard deviation $\left(\sigma_{\mathrm{P}}\right)$ to facilitate comparison across graphs. ${ }^{*} P<0.05 ; * * P$ $<0.01 ; * * *<0.001$. Refer to Table 1 for descriptions of the fatty acid groups studied. 
herd (feed) and genetics explain much more variation than did lactation stage or energy status.

\section{Changes in Milk Fat Composition with Lactation Stage}

For C6:0 to C14:0, several studies reported an increase during the first 3 mo of lactation and a decrease thereafter, whereas C18 FA follow an inverted pattern (Palmquist and Beaulieu, 1993; Kay et al., 2005;
Garnsworthy et al., 2006). The current study found similar results. Trans FA slightly decreased with lactation stage. Cis-9,trans-11 CLA increased with lactation stage. Trans-10,cis-12 CLA, C5-15, and the branched FA did not significantly change with lactation stage.

Fat percentage linearly increased during d 100 to 300 from 4.24 to $5.02 \%$ (results not shown). Short-chain FA (C4 to C14) seemed to peak around d 100, whereas long-chain FA of more than 16 carbons peaked (or were at a minimum) around d 150 to 200. This suggested
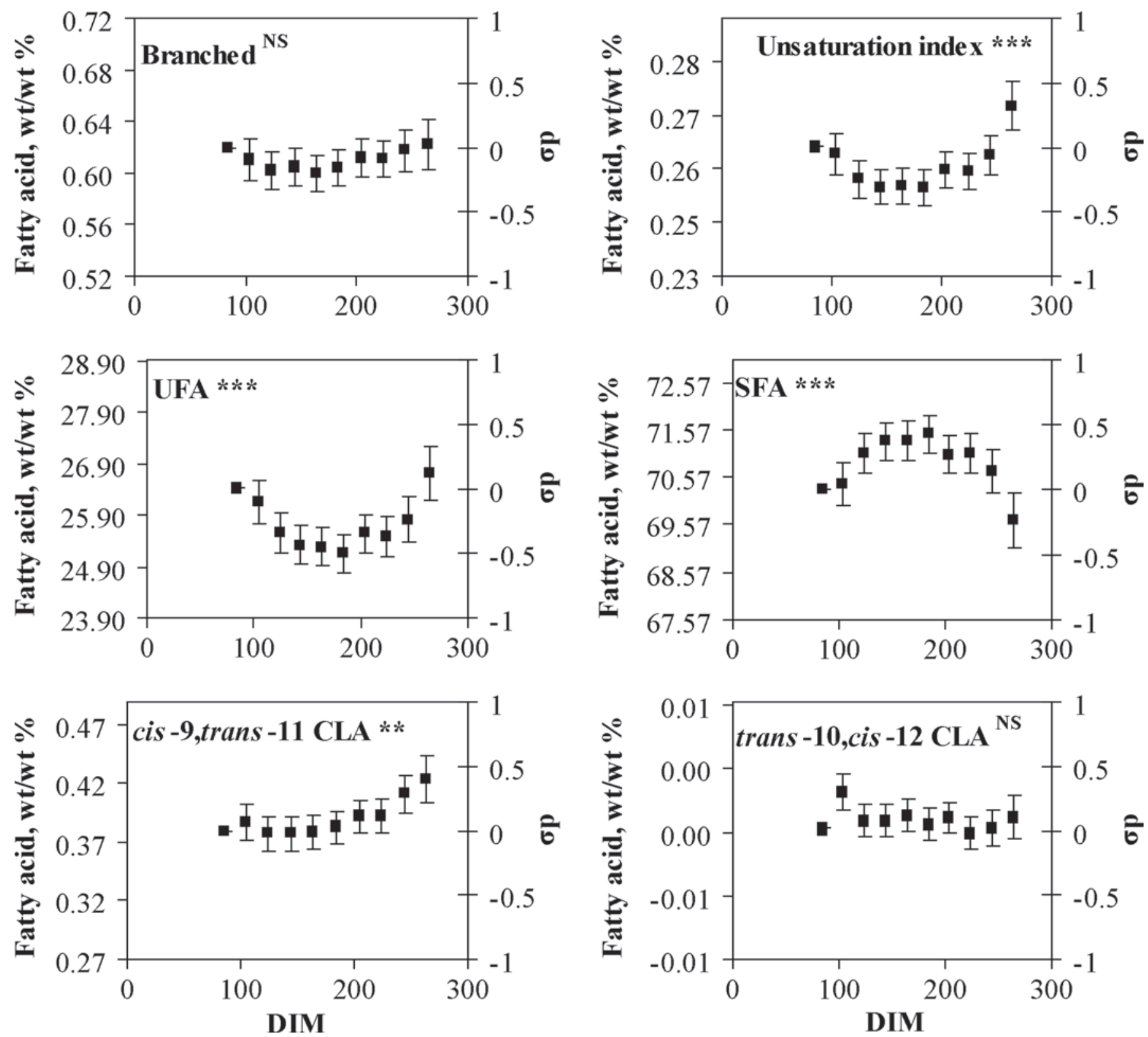

Figure 1 (continued). Changes in fatty acid proportions during lactation; x-axis shows days in lactation (DIM); left y-axis shows changes in fatty acid (\% wt/wt); and right y-axis shows relative change in phenotypic standard deviation $\left(\sigma_{\mathrm{P}}\right)$ to facilitate comparison across graphs. ${ }^{*} P$ $<0.05$; ${ }^{* *} P<0.01{ }^{* * *} P<0.001$. Refer to Table 1 for descriptions of the fatty acid groups studied. 
Table 3. Number of cows in each deviation of fat-to-protein ratio (FPdev) class, average lactation stage, fat percentage, protein percentage, fat yield, protein yield, milk yield, fat-to-protein ratio (FPratio), and FPdev ${ }^{1,2,3}$

\begin{tabular}{|c|c|c|c|c|}
\hline \multirow[b]{2}{*}{ Trait } & \multicolumn{3}{|c|}{ FPdev class } & \multirow[b]{2}{*}{$P$-value ${ }^{4}$} \\
\hline & $\begin{array}{c}\text { MFD } \\
(<-0.12)\end{array}$ & $\begin{array}{c}\text { Normal } \\
(-0.12 \text { to } 0.12)\end{array}$ & $\begin{array}{c}\text { NEB } \\
(>0.12)\end{array}$ & \\
\hline Cows (n) & 174 & 1,511 & 247 & \\
\hline Lactation stage range (d) & 66-249 & 63-282 & $66-263$ & \\
\hline Lactation stage $(d)$ & $158(43)$ & $168(40)$ & $169(42)$ & \\
\hline FPdev & $-0.21(0.12)$ & $0.00(0.06)$ & $0.21(0.16)$ & $<0.001$ \\
\hline FPratio & $1.05(0.19)$ & $1.23(0.13)$ & $1.45(0.21)$ & $<0.001$ \\
\hline Fat $(\%)$ & $3.77(0.78)$ & $4.33(0.60)$ & $4.93(0.82)$ & $<0.001$ \\
\hline Protein (\%) & $3.60(0.31)$ & $3.52(0.29)$ & $3.40(0.29)$ & $<0.001$ \\
\hline Fat yield (kg) & $0.51(0.13)$ & $0.58(0.10)$ & $0.60(0.12)$ & $<0.001$ \\
\hline Protein yield (kg) & $0.49(0.09)$ & $0.48(0.09)$ & $0.42(0.10)$ & $<0.001$ \\
\hline Milk yield $(\mathrm{kg})$ & $13.6(2.7)$ & $13.6(2.7)$ & $12.4(2.9)$ & $<0.001$ \\
\hline
\end{tabular}

${ }^{1} \mathrm{FPdev}$ is calculated as $\mathrm{FP}_{\text {sample }}-\mathrm{FP}_{\text {lactation }}$, where $\mathrm{FP}_{\text {lactation }}$ is based on approximately 7 test days. $\mathrm{MFD}=$ milk fat depression; NEB = negative energy balance.

${ }^{2}$ Yield traits are based on 1 morning sample.

${ }^{3}$ Standard deviation given in parentheses.

${ }^{4} P$-values are based on $t$-test.

that these changes in FA composition over lactation were not explained by changes in overall fat percentage.

\section{Changes in Milk Fat Composition with Energy Status}

Several studies have described FPratio as the milk trait best suited to predict energy status (Grieve et al., 1986; Friggens et al., 2007a; Van Knegsel et al., 2007).
Nonetheless, accuracy was not very high compared with studies in which DMI and BW are known (Heuer et al., 2000, 2001; Friggens et al., 2007a). De Vries and Veerkamp (2000) suggested that a deviation of average cow FPratio might be more appropriate to use, as it adjusts FPratio for genetic merit of individual cows. From Table 3 it follows that FPdev classified MFD and NEB as expected: the MFD class showed a significant decrease in fat percentage with no changes in other

Table 4. Differences in milk fat composition during milk fat depression (MFD) and negative energy balance (NEB), relative to normal individuals, estimated on 1,933 cows in first lactation ${ }^{1}$

\begin{tabular}{lccc}
\hline & \multicolumn{2}{c}{ FPdev $^{3}$} & \\
\cline { 2 - 3 } Trait $^{2}$ & $<-0.12(\mathrm{MFD})$ & $>0.12(\mathrm{NEB})$ & $P$-value \\
\hline C4:0 & $-0.094(0.025)^{\mathrm{a}, \mathrm{b}}$ & $0.031(0.018)^{\mathrm{a}, \mathrm{b}}$ & $<0.001$ \\
C6-12 & $0.143(0.109)^{\mathrm{b}}$ & $-0.301(0.075)^{\mathrm{a}, \mathrm{b}}$ & $<0.001$ \\
C14:0 & $0.061(0.08)^{\mathrm{b}}$ & $-0.326(0.058)^{\mathrm{a}, \mathrm{b}}$ & $<0.001$ \\
C5-15 & $0.040(0.029)^{\mathrm{b}}$ & $-0.084(0.020)^{\mathrm{a}, \mathrm{b}}$ & $<0.001$ \\
C16:0 & $-0.681(0.255)^{\mathrm{a}, \mathrm{b}}$ & $0.696(0.178)^{\mathrm{a}, \mathrm{b}}$ & $<0.001$ \\
C18:0 & $-0.128(0.135)^{\mathrm{b}}$ & $0.467(0.093)^{\mathrm{b}}$ & $<0.001$ \\
C18tr & $0.072(0.036)^{\mathrm{a}}$ & $0.006(0.029)$ & 0.04 \\
C18u & $0.436(0.221)^{\mathrm{a}, \mathrm{b}}$ & $-0.194(0.153)^{\mathrm{a}, \mathrm{b}}$ & 0.02 \\
Branched & $-0.001(0.009)^{\mathrm{a}, \mathrm{b}}$ & $-0.010(0.006)$ & 0.20 \\
Unsaturation index & $0.005(0.003)^{\mathrm{a}, \mathrm{b}}$ & $-0.005(0.002)^{\mathrm{a}, \mathrm{b}}$ & $<0.001$ \\
Unsaturated fatty acids & $0.523(0.227)^{\mathrm{a}, \mathrm{b}}$ & $-0.365(0.156)^{\mathrm{a}, \mathrm{b}}$ & $<0.001$ \\
Saturated fatty acids & $-0.617(0.246)^{\mathrm{a}, \mathrm{b}}$ & $0.448(0.170)^{\mathrm{a}, \mathrm{b}}$ & $<0.001$ \\
Cis-9,trans-11 CLA ${ }^{\mathrm{a}}$ & $0.009(0.009)^{\mathrm{b}}$ & $-0.020(0.006)^{\mathrm{a}, \mathrm{b}}$ & $<0.001$ \\
Trans-10, cis-12 CLA & $0.002(0.001)^{\mathrm{a}, \mathrm{b}}$ & $-0.001(0.001)^{\mathrm{a}, \mathrm{b}}$ & $<0.001$ \\
\hline
\end{tabular}

${ }^{\mathrm{a}}=$ significantly different $(P<0.05)$ from normal deviation of the fat-to-protein ratio (FPdev) class.

${ }^{\mathrm{b}}=$ significant difference between MFD and NEB individuals.

${ }^{1} \mathrm{FPdev}$ is calculated as $\mathrm{FP}_{\text {sample }}-\mathrm{FP}_{\text {lactation, }}$, where $\mathrm{FP}=$ fat-to-protein ratio, and $\mathrm{FP}_{\text {lactation }}$ is based on approximately 7 test days. MFD = milk fat depression; $\mathrm{NEB}=$ negative energy balance.

${ }^{2}$ Groups are defined in Table 1 .

${ }^{3}$ Standard errors are given in parentheses.

${ }^{4} \mathrm{CLA}=$ conjugated linoleic acid 
Table 5. F-values for lactation stage (model 1), deviation of the fat-to-protein ratio (FPdev, model 2), or both (model 3) to compare significance of the effects of lactation stage and FPdev ${ }^{1}$

\begin{tabular}{|c|c|c|c|c|}
\hline \multirow[b]{2}{*}{ Trait $^{2}$} & \multirow{2}{*}{$\frac{\text { Model } 1}{\text { Lactation stage }}$} & \multirow{2}{*}{$\frac{\text { Model } 2}{\text { FPdev }}$} & \multicolumn{2}{|c|}{ Model 3} \\
\hline & & & Lactation stage & FPdev \\
\hline $\mathrm{C} 4: 0$ & 2.45 & 12.93 & 2.56 & 13.59 \\
\hline C6-12 & 5.55 & 10.20 & 5.42 & 9.55 \\
\hline C14:0 & 3.28 & 16.83 & 3.02 & 16.13 \\
\hline C5-15 & 1.44 & 11.48 & 1.34 & 11.03 \\
\hline C16:0 & 9.05 & 15.03 & 8.82 & 14.36 \\
\hline C18:0 & 8.34 & 14.14 & 8.30 & 14.80 \\
\hline C18tr & 3.01 & 3.15 & 2.78 & 2.41 \\
\hline $\mathrm{C} 18 \mathrm{u}$ & 5.98 & 4.20 & 5.71 & 3.88 \\
\hline Branched & 0.93 & 1.59 & 0.95 & 1.75 \\
\hline Unsaturation index & 4.06 & 7.33 & 4.09 & 7.90 \\
\hline Unsaturated fatty acids & 4.37 & 7.67 & 4.29 & 7.87 \\
\hline Saturated fatty acids & 4.29 & 9.36 & 4.25 & 9.68 \\
\hline Cis-9,trans-11 CLA $^{3}$ & 2.48 & 7.26 & 2.58 & 7.81 \\
\hline Trans-10, cis-12 CLA & 1.55 & 7.19 & 1.51 & 6.91 \\
\hline \multicolumn{5}{|c|}{ 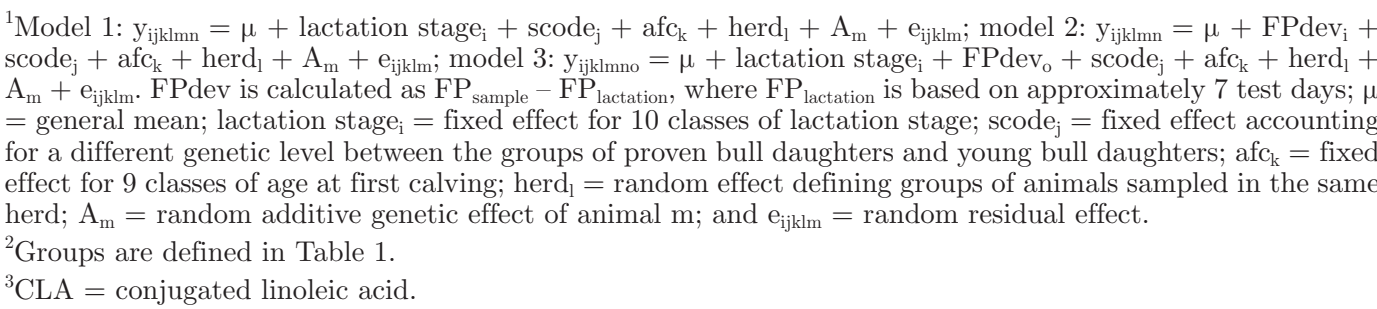 } \\
\hline
\end{tabular}

milk production traits, and the NEB class showed an increased fat percentage, and decreased protein and milk yield. Still, a cow that remains in NEB throughout lactation would be wrongly classified as a normal cow. This would result in smaller differences between the groups of normal and NEB cows, which would result in underestimation of the actual effect of energy balance on milk fat composition. The same situation applies to cows that show MFD throughout lactation. The results showed that $13 \%$ of animals were classified as NEB and 9\% were classified as MFD. As an energy indicator, FPdev could not explain the effect of lactation stage. The largest changes in energy status and most severe NEB are expected in the first few weeks of lactation, mainly in animals of greater parity (Friggens et al., 2007b). In the current study, animals classified as NEB were not limited to early lactation. Possible reasons why these animals had elevated FPratio compared with their lactation average could be changes in or problems with feed (Hermansen, 1995), pregnancy, overall body condition, and health (Heuer et al., 1999). Available data on feed, insemination dates, BCS, and fertility were too limited to associate causes for the observed NEB.

Energy indicator FPdev significantly affected milk fat composition. Milk fat depression (low FPdev) led to increased levels of trans FA (C18tr), cis-9, trans-11 CLA, and trans-10, cis-12 CLA (Table 4), which might reflect altered or incomplete biohydrogenation activity in the rumen (Bauman and Griinari, 2003; Bauman et al., 2008; Plaizier et al., 2008). According to Bauman and Griinari (2003) this altered rumen biohydrogenation would lead to more C18:1 trans intermediates, particularly C18:1 trans-10, which can then be converted to trans-10, cis-12 CLA, possibly explaining the increased levels of C18tr and trans-10,cis-12 CLA in the current study. It was expected that the increase in longchain FA in MFD cows would inhibit de novo synthesis of $\mathrm{C} 6: 0$ to C16:0 fatty acids. Overall fat percentage and $\mathrm{C} 16: 0$ were decreased, but the proportion of $\mathrm{C} 6: 0$ to C14:0 was not different from that of normal cows. Palmquist and Beaulieu (1993) suggested that inhibition by long-chain FA increased from C6:0 to C16:0, as longer chains require more acetyl unit addition via malonyl CoA, which might explain why the inhibiting effect was only observed in C16:0.

Negative energy balance (high FPdev) led to greater proportions of SFA, mainly C16:0 and some C18:0, and a decrease in UFA (Table 4). This result supported those of Stoop et al. (2008) and Karijord et al. (1982), who found positive genetic correlations between fat percentage and SFA and negative genetic correlations between fat percentage and UFA. Additional calculations were performed to study to what extent the effects of high FPdev were due to an increase in fat percentage. Fat percentage was added as a covariate 
to model [2]. Changes in fat percentage explained only part of the effect for NEB, depending on the size of the genetic correlation.

Clarke (1993) suggested that most fat deposition in body fat reserves in production animals is de novosynthesized C16:0 and C18:0. During NEB, cows mobilize these body fat reserves, which consequently leads to increased proportions of C16:0 and C18:0 in milk, as observed in the current study. Negative energy balance resulted in less $\mathrm{C} 5-15$. These FA can be synthesized from C3 components. During NEB C3 components were redirected to the increased production of among others, lactose. This redirection results in a relative C3 shortage, explaining the decrease in C5-15 (Van Knegsel et al., 2005). Our result showed that a morenegative energy status (reflected by high FPdev) led to less-favorable milk fat composition: C16:0 was relatively high, whereas the unsaturated C18 FA were relatively low.

\section{CONCLUSIONS}

Moderate changes in milk fat composition were found with lactation stage of 0.5 to 1 phenotypic SD for most FA. Effect of lactation stage could not be explained by energy status. Cows with MFD generally had increased levels of C18tr and CLA, which might point to physiological disturbances, incomplete biohydrogenation in the rumen, and possible acidosis. Cows with NEB generally had decreased levels of C5-15 and increased levels of C16:0 and C18:0, indicating possible energy shortage and reallocation of $\mathrm{C} 3$ components in the FA de novo synthesis, as well as body fat reserve mobilization. Our study showed that both lactation stage and energy balance significantly contribute to variation in milk fat composition and alter the activity of different fatty acid pathways.

\section{ACKNOWLEDGMENTS}

This study was part of the Milk Genomics Initiative, funded by Wageningen University, NZO (Dutch Dairy Organization), breeding company HG, and technology foundation STW. The authors thank the owners of the herds, the Milk Control Station (Zutphen, the Netherlands), and NRS (Arnhem, The Netherlands) for their help in collecting the data, and Nicolas Friggens (Faculty of Agricultural Sciences, Tjele, Denmark) for his highly appreciated comments on the manuscript.

\section{REFERENCES}

Bauman, D. E., and J. M. Griinari. 2003. Nutritional regulation of milk fat synthesis. Annu. Rev. Nutr. 23:203-227.
Bauman, D. E., J. W. Perfield II, K. J. Harvatine, and L. H. Baumgard. 2008. Regulation of fat synthesis by conjugated linoleic acid: Lactation and the ruminant model. J. Nutr. 138:403-409.

Calus, M. P. L., M. J. Carrick, R. F. Veerkamp, and M. E. Goddard. 2005. Estimation of genetic parameters for milk fat depression in dairy cattle. J. Dairy Sci. 88:1166-1177.

Chilliard, Y., A. Ferlay, R. M. Mansbridge, and M. Doreau. 2000. Ruminant fat plasticity: Nutritional control of saturated, polyunsaturated, trans and conjugated fatty acids. Ann. Zootech. 49:181-205.

Clarke, S. D. 1993. Regulation of fatty acid synthase gene expression: An approach for reducing fat accumulation. J. Anim. Sci. 71:1957-1965.

De Vries, M. J., and R. F. Veerkamp. 2000. Energy balance of dairy cattle in relation to milk production variables and fertility. J. Dairy Sci. 83:62-69.

Friggens, N. C., P. Berg, P. Theilgaard, I. R. Korsgaard, K. L. Ingvartsen, P. Lovendahl, and J. Jensen. 2007b. Breed and parity effects on energy balance profiles through lactation: Evidence of genetically driven body energy change. J. Dairy Sci. 90:52915305.

Friggens, N. C., C. Ridder, and P. Lovendahl. 2007a. On the use of milk composition measures to predict energy balance in dairy cows. J. Dairy Sci. 90:5453-5467.

Garnsworthy, P. C., L. L. Masson, A. L. Lock, and T. T. Mottram. 2006. Variation of milk citrate with stage of lactation and de novo fatty acid synthesis in dairy cows. J. Dairy Sci. 89:1604-1612.

German, J. B., and C. J. Dillard. 2006. Composition, structure and absorption of milk lipids: A source of energy, fat-soluble nutrients and bio-active molecules. Crit. Rev. Food Sci. Nutr. 46:57-92.

Gilmour, A. R., B. J. Gogel, B. R. Cullis, S. J. Welham, and R. Thompson. 2002. ASReml User Guide Release 1.0. VSN International Ltd., Hemel Hempstead, UK.

Grieve, D. G., S. Korver, Y. S. Rijpkema, and G. Hof. 1986. Relationship between milk composition and some nutritional parameters in early lactation. Livest. Prod. Sci. 14:239-254.

Hermansen, J. E. 1995. Prediction of milk fatty acid profile in dairy cows fed dietary fat differing in fatty acid composition. J. Dairy Sci. 78:872-879.

Heuer, C., Y. H. Schukken, and P. Dobbelaar. 1999. Postpartum body condition score and results from the first test day milk as predictors of disease, fertility, yield, and culling in commercial dairy herds. J. Dairy Sci. 82:295-304.

Heuer, C., W. M. van Straalen, Y. H. Schukken, A. Dirkzwager, and J. P. T. M. Noordhuizen. 2000. Prediction of energy balance in a high yielding dairy herd in early lactation: Model development and precision. Livest. Prod. Sci. 65:91-105.

Heuer, C., W. M. van Straalen, Y. H. Schukken, A. Dirkzwager, and J. P. T. M. Noordhuizen. 2001. Prediction of energy balance in high yielding dairy cows with test-day information. J. Dairy Sci. 84:471-481.

IDF. 2002a. ISO 15884-IDF 182. Milk-fat - Preparation of fatty acid methyl esters. International Dairy Federation, Brussels, Belgium.

IDF. 2002b. ISO 15885-IDF 184. Milk-fat - Determination of the fatty acid composition by gas-liquid chromatography. International Dairy Federation, Brussels, Belgium.

Karijord, O., N. Standal, and O. Syrstad. 1982. Sources of variation in composition of milk fat. Z. Tierzucht. Biol. 99:81-93.

Kay, J. K., W. J. Weber, C. E. Moore, D. E. Bauman, L. B. Hansen, H. Chester-Jones, B. A. Crooker, and L. H. Baumgard. 2005. Effects of week of lactation and genetic selection for milk yield on milk fatty acid composition in Holstein cows. J. Dairy Sci. 88:3886-3893.

MacGibbon, A. K. H., and M. W. Taylor. 2006. Composition and structure of bovine milk lipids. Pages 1-42 in Advanced Dairy Chemistry. Vol. 2: Lipids. 3rd ed. P. F. Fox and P. L. H. McSweeney, ed. Springer, New York, NY.

Palmquist, D. L., and A. D. Beaulieu. 1993. Feed and animal factors influencing milk fat composition. J. Dairy Sci. 76:1753-1771. 
Plaizier, J. C., D. O. Krause, G. N. Gozho, and B. W. McBride. 2008. Subacute ruminal acidosis in dairy cows: The physiological causes, incidence and consequences. Vet. J. 176:21-31.

Stoop, W. M., J. A. M. van Arendonk, J. M. L. Heck, H. J. F. van Valenberg, and H. Bovenhuis. 2008. Genetic parameters for major milk fatty acids and milk production traits of Dutch Holstein Friesians. J. Dairy Sci. 91:385-394.

Syrstad, O., N. Standal, and O. Karijord. 1982. Concentration of various fatty acids in milk. Z. Tierzucht. Biol. 99:94-100.
Van Knegsel, A. T. M., H. van den Brand, J. Dijkstra, S. Tamminga, and B. Kemp. 2005. Effect of dietary energy source on energy balance, production, metabolic disorders and reproduction in lactating dairy cattle-Review. Reprod. Nutr. Dev. 45:665-688.

Van Knegsel, A. T. M., H. van den Brand, J. Dijkstra, W. M. van Straalen, M. J. W. Heetkamp, S. Tamminga, and B. Kemp. 2007. Dietary energy source in dairy cows in early lactation: Energy partitioning and milk composition. J. Dairy Sci. 90:1467-1476. 